\title{
Chile Pepper Sensitivity to Mustard Seed Meal Applied after Crop Emergence
}

\author{
Asmita Nagila, Brian J. Schutte, and Soum Sanogo \\ Department of Entomology, Plant Pathology and Weed Science, New Mexico \\ State University, 945 College Drive, Las Cruces, NM 88003
}

\section{Omololu John Idowu \\ Department of Extension Plant Sciences, New Mexico State University, 945 College Drive, Las Cruces, NM 88003}

Additional index words. Amaranthus palmeri, Brassicaceae seed meal, Capsicum annuum, chili pepper, integrated pest management, Phytophthora capsici

\begin{abstract}
When applied before crop emergence, soil amendments with mustard seed meal (MSM) control some weeds and soilborne pathogens. MSM applications after crop emergence (herein "postemergence applications") might be useful components of agricultural pest management programs, but research on postemergence applications of MSM is limited. The overall objective of this investigation was to develop a method for postemergence application of MSM that does not cause irrecoverable injury or yield loss in chile pepper (Capsicum annuum). To accomplish this objective, we conducted a sequence of studies that evaluated different MSM rates and application methods in the greenhouse and field. For the greenhouse study, we measured chile plant photosynthetic and growth responses to MSM applied postemergence on the soil surface or incorporated into soil. For the field study, we determined chile pepper fruit yield responses to MSM applied postemergence using a technique based on the method developed in greenhouse, and we confirmed that the MSM rates used in our study (4400 kg.ha ${ }^{-1}$ and $2200 \mathrm{~kg} \cdot \mathrm{ha}^{-1}$ ) inhibited the emergence of the weed Palmer amaranth (Amaranthus palmeri) and the growth of the pathogen Phytophthora capsici, which are common problems in chile pepper production in New Mexico. Greenhouse study results indicated that MSM at 4400 $\mathrm{kg} \cdot \mathrm{ha}^{-1}$ spread on the soil surface caused irrecoverable injury to chile pepper plants; however, chile pepper plants were not permanently injured by the following three treatments: 1) MSM at $4400 \mathrm{~kg} \cdot \mathrm{ha}^{-1}$ incorporated into soil, 2) MSM at $2200 \mathrm{~kg} \cdot \mathrm{ha}^{-1}$ spread on the soil surface, and 3) MSM at $2200 \mathrm{~kg} \cdot \mathrm{ha}^{-1}$ incorporated into soil. For the field study, postemergence, soil-incorporated applications of MSM at $4400 \mathrm{~kg} \cdot \mathrm{ha}^{-1}$ suppressed emergence of Palmer amaranth by $89 \%$ and reduced mycelial growth of Phytophthora capsica by $96 \%$. Soil-incorporated applications of MSM at $2200 \mathrm{~kg} \cdot \mathrm{ha}^{-1}$ suppressed emergence of Palmer amaranth by $41.5 \%$ and reduced mycelial growth of Phytophthora capsica by $71 \%$. Postemergence soil-incorporated applications of MSM did not reduce chile pepper yield compared with the control. The results of this study indicated that MSM applied after crop emergence and incorporated into soil can be a component of pest management programs for chile pepper.
\end{abstract}

Chile pepper (Capsicum annuum) is an important horticultural crop in New Mexico. In $2018, \approx 8400$ acres in New Mexico were cultivated with chile pepper, which comprised $46 \%$ of total chile pepper acreage in the United States [U.S. Dept. Agr., National Agricultural Statistics Service (NASS), 2019]. Chile pepper in New Mexico is grown for green and red fruits that are each purchased by both food processors and fresh markets. The value of chile pepper production in 2018 was $\$ 53.8$ million, with chile pepper for processing valued at $\$ 43.8$ million and chile pepper for fresh markets valued at \$10.0 million (U.S. Dept. Agr., NASS, 2019). The extent and monetary worth of chile pepper production in New Mexico is partly a consequence of four centuries of chile pepper production in this region (Bosland, 2015).
In New Mexico, chile pepper is typically seeded in March to April, the crop stand is thinned in May, and chile peppers are harvested for green fruits from August to September or for red fruits from September to October (Hawkes et al., 2008). In mid- to-late summer, monsoonal rains stimulate both soilborne diseases (Matheron and Porchas, 2015; Sanogo and Carpenter, 2006) and emergence of weeds that potentially reduce chile pepper fruit yield (Schroeder, 1993). To manage soilborne diseases, growers preemptively use systemic fungicides, synthetic fumigants, and biofungicides in combination with cultural tactics including crop rotation and soil water management to avoid prolonged saturation (Sanogo and $\mathrm{Ji}, 2013$ ). To control mid- to-late season weeds, growers often rely on hand-hoeing because larger chile pepper plants preclude mechanical cultivation and label regulations limit herbicide applications during latter stages of crop development. However, despite these management efforts, soilborne pathogens and mid- to-late season weeds continue to cause substantial losses in chile pepper yield (Sanogo and Carpenter, 2006) and chile pepper production profitability (Skaggs et al., 2000).

MSMs are byproducts from crushing rape (Brassica napus), brown mustard (Brassica juncea), or white mustard (Sinapis alba) seeds for biodiesel production. MSMs have fungicidal, nematocidal, and herbicidal properties (Borek et al., 1995; Hoagland et al., 2008; Wang et al., 2015; Yu et al., 2005) because MSMs contain high concentrations of plant secondary metabolites known as glucosinolates (Bhandari et al., 2015). When MSM is hydrated in soil, glucosinolates are converted by the enzyme myrosinase into a variety of products including volatile isothiocyanates (Kirkegaard and Sarwar, 1998). In laboratory studies, volatile isothiocyanates strongly suppressed growth of soilborne pathogens (Charron and Sams, 2017; Gigot et al., 2013; Mayton et al., 1996) and weeds (Wang et al., 2015; Wood et al., 2020). In field studies, MSM reduced densities of annual weeds (Bañuelos and Hanson, 2010; Boydston et al., 2018; Hoagland et al., 2008) and incidence of soilborne disease (Fayzalla et al., 2009). The physiological mechanisms of action for MSM are not well understood, but specific isothiocyanates are associated with stomatal closure (Hossain et al., 2013) and disruption of microtubule networks (Øverby et al., 2015). Isothiocyanates also interfere with adenosine triphosphate binding sites (Breier et al., 1989) and inhibit physiological processes during seedling growth (Leblová-Svobodová and Koštír, 1962; Urbancsok et al., 2017). Accordingly, MSM is mainly used to suppress weeds before emergence (Wang et al., 2015), although MSM can also inhibit growth of emerged plants (Webber et al., 2017).

Use of MSM requires measures to protect the crop because MSM can negatively affect crop seed germination and growth. For example, Earlywine et al. (2010) determined that MSM reduced stand densities of desirable turfgrass species by $77 \%$ to $81 \%$ compared with a nontreated control. MSMs have also been reported to reduce seedling emergence of lettuce (Lactuca sativa), carrot (Daucus carota), cotton (Gossypium hirsutum), and raspberry (Rubus ideaus) (Gigot et al., 2013; Meyer et al., 2011; Rothlisberger et al., 2012; Snyder et al., 2009). MSM derived from brown mustard caused injury on strawberry (Fragaria ananassa) and sweet corn (Zea mays) (Yu et al., 2007), although MSM-induced injury on potato (Solanum tuberosum) was not associated with yield loss (Boydston et al., 2018). In onion, MSM applications at the cotyledon and one-leaf stage caused high rates of plant mortality in a greenhouse study; however, in the field, applications of MSM at the two-leaf stage caused only visual injury on onion and did not reduce yield (Boydston et al., 2011).

MSM applications 3 weeks before chile pepper seeding (i.e., preplant applications) reduced weed densities and hoeing times 
early in the growing season (Wood, 2019). These results were consistent with previous studies that determined preplant applications of MSM lowered early season weed density but often failed to control later-emerging weeds (Boydston et al., 2018; Shrestha et al., 2015; Webber et al., 2017). In chile pepper, MSM applications after crop emergence (i.e., postemergence applications) could be a tactic for simultaneously targeting weeds and soilborne pathogens during middle and later phases of the growing season. To our knowledge, postemergence applications of MSM have yet to be studied in chile pepper.

The primary objective for this investigation was to develop a method for postemergence applications of MSM that does not cause irrecoverable injury or fruit yield loss in chile pepper. To accomplish this objective, we conducted a sequence of studies that evaluated different MSM rates and application methods in the greenhouse and field. For the greenhouse study, we measured chile plant photosynthetic and growth responses to postemergence applications of MSM that were either spread on the soil-surface or incorporated into soil. Results from the greenhouse study informed field evaluations of our method for postemergence MSM applications. Specifically, we conducted a field study to 1) determine chile pepper fruit yield responses to postemergence applications of MSM administered using a technique based on the method developed in the greenhouse, and 2) confirm that the MSM rates used in our study inhibit emergence of a weed (Palmer amaranth, Amaranthus palmeri) and growth of a soilborne pathogen (Phytophthora capsici) that are common problems during the middle and later phases of chile pepper production in New Mexico.

\footnotetext{
Received for publication 21 Sept. 2020. Accepted for publication 6 Dec. 2020.

Published online 14 January 2021.

Funding for this research was provided by the Western Sustainable Agriculture Research and Education program (project SW18-059), the National Institute of Food and Agriculture, and the U.S. Department of Agriculture. Additional salaries and research support were provided by state and federal funds appropriated to the New Mexico State University Agricultural Experiment Station. We gratefully acknowledge the field assistance of Joshua Bleiwess, Ed Morris, and Israel Marquez, as well as the technical assistance from staff at the Leyendecker Plant Science Research Center and Los Lunas Agriculture Research Center. We also thank our chile pepper grower collaborators, as well as Erik Lehnhoff and Ivette Guzman for reviewing this paper.

This paper is a portion of a thesis submitted by Asmita Nagila in fulfilling an MS degree requirement.

B.J.S. is the corresponding author. E-mail: bschutte@ nmsu.edu.

This is an open access article distributed under the CC BY-NC-ND license (https://creativecommons. org/licenses/by-nc-nd/4.0/).
}

\section{Materials and Methods}

Biological materials. Mustard seed meal derived from brown mustard was purchased from a commercial supplier in Aug. 2018 (Pescadero Gold; Farm Fuel Inc., Freedom, CA). When not in use, MSM was stored in plastic bags at room temperature (20 to $25{ }^{\circ} \mathrm{C}$ ). The concentration of sinigrin, the primary glucosinolate in brown mustard seed meal, was $203 \mu \mathrm{mol} \cdot \mathrm{g}^{-1}$. This concentration was determined with high-performance liquid chromatography (Agilent 1100; Agilent Technologies, Santa Clara, CA) following methods in Doheny-Adams et al. (2017). For the MSM in this study, the concentration of sinigrin was sufficient for pesticidal activity (Bangarwa et al., 2011; Meyer et al., 2015).

In Sept. 2018, seeds of Palmer amaranth were collected from the New Mexico State University (NMSU) Leyendecker Plant Science Research Center (32.198 N, 106.742 W), south of Las Cruces, NM. Palmer amaranth inflorescences were removed from the field and hand-thrashed with sequential combinations of sieving and forced-air separation until seeds were separated from chaff. Seeds were stored in an airtight container at $4{ }^{\circ} \mathrm{C}$.

A virulent isolate of Phytophthora capsici (isolate 6347), recovered from a fieldinfected chile pepper plant in Doña Ana County, NM, was used (Jiang et al., 2015). Cultures of isolate 6347 were maintained at $25^{\circ} \mathrm{C}$ on autoclaved $\mathrm{V} 8$ agar media $(800 \mathrm{~mL}$ distilled water, $200 \mathrm{~mL}$ V8 juice, $2 \mathrm{~g} \mathrm{CaCO}_{3}$, $20 \mathrm{~g}$ technical agar).

Greenhouse study. A study was conducted in a greenhouse located at the NMSU Leyendecker Plant Science Research Center. The study consisted of two experimental runs. Experimental run 1 was carried out from 4 Mar. 2019 to 5 June 2019. The air temperature in the greenhouse was maintained at $24^{\circ} \mathrm{C}\left( \pm 3{ }^{\circ} \mathrm{C}\right)$ and supplemental light was not provided because ambient light conditions supported chile pepper growth and development. Experimental run 2 was performed from 16 Dec. 2019 to 26 Mar. 2020. For the second experimental run, the air temperature in the greenhouse was maintained at $24{ }^{\circ} \mathrm{C}( \pm$ $3{ }^{\circ} \mathrm{C}$ ) and a photoperiod of 14-h light and 10 $\mathrm{h}$ dark was maintained by operating highintensity discharge metal halide lamps from 6:00 to 8:00 AM and from 5:00 to 8:00 PM.

Experimental units were bins $(30 \mathrm{~cm}$ long, $25 \mathrm{~cm}$ wide, $15 \mathrm{~cm}$ deep) containing three chile pepper plants positioned in a row that was situated central and parallel to the longitudinal axis of the bin. The planting medium was a sandy loam soil $(79 \%$ sand, $9 \%$ silt, $12 \%$ clay) with $\mathrm{pH}$ of 8.2 and organic matter of $0.7 \%$. The soil was collected from a field at the NMSU Leyendecker Plant Science Research Center. Soil with high sand content was selected because sand was expected to facilitate drainage in bins. Before use, soil was sieved to remove debris that did not passed through a 4-mm screen. Each bin was filled with soil to a depth of $11 \mathrm{~cm}$. The undersides of bins featured 9-mm diameter holes for drainage.
Chile pepper plants were started from seeds buried $2 \mathrm{~cm}$ in soil within the bins. The chile pepper cultivar was NM 6-4, which is susceptible to $P$. capsici. Before chile pepper seedling emergence, bins were subirrigated by placement in a larger container with water. After chile pepper seedling emergence, bins were surface irrigated with sprinkler canisters as required. Bins were not irrigated for $48 \mathrm{~h}$ before MSM application to ensure soil was dry for MSM application. MSM was applied 8 weeks after chile pepper emergence. Immediately after MSM application, bins were irrigated to saturation $(3 \mathrm{~L}$ water/bin).

Treatments were arranged on the greenhouse bench in a randomized complete block design with four replications. Treatments consisted of factorial combinations of MSM rate (high rate and low rate) and MSM placement (soil surface and soil incorporated). Treatments also included a control that lacked both MSM and soil disturbance associated with MSM incorporation. Herein, the combinations of MSM rates and placements are referred to as "low surface," "low incorporated," "high surface," and "high incorporated." The high rate treatment was $33 \mathrm{~g} / \mathrm{bin}$ MSM, which corresponds to a field application rate of $4400 \mathrm{~kg} \cdot \mathrm{ha}^{-1} \mathrm{MSM}$. The low rate treatment was $16.5 \mathrm{~g} / \mathrm{bin}$ MSM, which corresponds to a field application rate of $2200 \mathrm{~kg} \cdot \mathrm{ha}^{-1}$. The application rates 2200 and $4400 \mathrm{~kg} \cdot \mathrm{ha}^{-1}$ were recommended by the supplier and previously shown to suppress soilborne pathogens (Wood et al., 2020). For soil surface treatments, MSM was applied on the soil surface in two bands that ran parallel to the chile pepper row, $2 \mathrm{~cm}$ from chile pepper plants. For soil-incorporated treatments, two trenches ( $5 \mathrm{~cm}$ depth) were dug on either side of the chile pepper row, $2 \mathrm{~cm}$ from chile pepper plants. MSM was applied evenly across the length of the trench, which was then closed with slight mixing of MSM and soil.

Photosynthetic rates of the youngest, fully open leaf were recorded immediately before MSM application and every $2 \mathrm{~d}$ until $14 \mathrm{~d}$ after application (DAA). Photosynthetic rates were determined with an IR gas analyzerbased photosynthesis system (LI-6400; LICOR Biosciences Inc., Lincoln, NE), which was equipped with a light-emitting diode that provided $800 \mu \mathrm{mol} \cdot \mathrm{m}^{-2} \cdot \mathrm{s}^{-1}$ of photosynthetically active radiation $(P A R)$ to leaf surfaces. This level of $P A R$ about matched the average light level at chile pepper plant height in the greenhouse. $\mathrm{CO}_{2}$ reference was set at 400 $\mu \mathrm{mol} \cdot \mathrm{mol}^{-1}$, and flow rate was set at 500 $\mathrm{mol} \cdot \mathrm{s}^{-1}$. Gas exchange measurements were taken after net photosynthesis and stomatal conductance values stabilized on the graphical display of the instrument's console.

At 14 DAA, plants were assessed for visual symptoms of injury from MSM using a scoring system of zero to 10 . Zero indicated no visual difference from nontreated control. The injury rating " 1 " indicated plants with droopy lower leaves, " 2 " indicated plants with droopy lower and upper leaves, " 3 " indicated wilting and " 4 " indicated chlorosis, "5" through "7" indicated increasing 
chlorosis and detachment of leaves, " 8 " and "9" indicated increasing degrees of leaf detachment with stunting, and "10" indicated plant death. Survival percentages of plants in each experimental unit were recorded. Also, at 14 DAA, plant height was determined by measuring the distance from the soil surface to the uppermost leaf without extending the leaf. Plants were then destructively sampled to determine aboveground weight and total leaf area using an area meter (LI-3100; LI-COR Biosciences, Lincoln, NE). Dry aboveground weight was determined after plant materials were dried for $3 \mathrm{~d}$ in an oven set to $65^{\circ} \mathrm{C}$.

Field study. There were four sites for this study. Two were commercial chile pepper fields near Deming, NM (32.225 N, 107.775 W) and Las Uvas, NM (32.605 N, 107.350 $\mathrm{W})$, and two were chile pepper fields at research farms managed by NMSU (Leyendecker Plant Science Research Center, south of Las Cruces (32.202 N, 106.743 W) and Agricultural Science Center at Los Lunas (34.769 N, 106.763 W). At the Deming site, soil was a Maricopa sandy, mixed, superactive, calcareous, thermic typic Torrifluvents $(56 \%$ sand, $14 \%$ silt, $30 \%$ clay; $2.5 \%$ organic matter). At the Las Uvas site, soil was a Mohave fine-loamy, mixed, superactive, thermic typic Calciargids (52\% sand, 24\% silt, $24 \%$ clay; $2.3 \%$ organic matter). Soil at Los Lunas was a Vinton sandy mixed typic Torrifluvents ( $82 \%$ sand, $6 \%$ silt, $12 \%$ clay; $0.6 \%$ organic matter) and soil at the Las Cruces site was a Glendale fine-silty, mixed, superactive, calcareous, thermic typic Torrifluvents ( $26 \%$ sand, $36 \%$ silt, $38 \%$ clay; $1.9 \%$ organic matter). Chile peppers were direct seeded in raised beds and grown using sitespecific practices customary for the region in 2019. Study sites differed in chile pepper cultivar. 'Sandia' was grown at the Las Cruces and Los Lunas sites, 'AZ-4' was grown at Las Uvas, and 'AZ-1904' at Deming.

Experimental units consisted of plots that were $6 \mathrm{~m}$ long and 3 chile pepper rows wide. The distance between adjacent chile pepper rows was site-specific. At the Las Cruces and Deming sites, chile pepper rows were spaced $1 \mathrm{~m}$ apart. At Los Lunas and Las Uvas, chile pepper rows were spaced $0.75 \mathrm{~m}$ apart. Treatments included incorporated applications of MSM at high (4400 $\left.\mathrm{kg} \cdot \mathrm{ha}^{-1}\right)$ and low (2200 $\mathrm{kg} \cdot \mathrm{ha}^{-1}$ ) rates. MSM rates were studied separately using a paired plot design with four replications (Perecin et al., 2015). Nontreated control plots were immediately adjacent to longitudinal axes of MSM treatment plots. At the time of MSM application, which was 10 to 11 weeks after the chile plant emergence, chile pepper plants were 40 to $60 \mathrm{~cm}$ tall.

MSM was applied by hand to furrows on both sides of central chile pepper rows. Each band of MSM spanned the length of the treatment plot. Immediately after application, MSM was incorporated into soil to a depth of $7 \mathrm{~cm}$ using a gas-powered rototiller (Mantis Tiller/Cultivator 7940; Schiller Grounds Care Inc., Southampton, PA). Furrows in nontreated plots were rototilled in a manner identical to furrows in treatment plots. All plots were then irrigated by hand with sprinkler canisters. The irrigation volume $(20 \mathrm{~L} /$ plot) was enough to saturate the upper $7 \mathrm{~cm}$ soil. MSM was applied only to furrows for two reasons: 1) rototilling on raised beds would likely have caused severe injury to chile plant roots, and 2) newly emerged weeds in furrows potentially interfere with chile pepper production, whereas weeds in the crop row are often suppressed by the chile pepper crop during the later phases of the growing season.

After MSM incorporation but before irrigation, and at $28 \mathrm{DAA}$, the upper $7 \mathrm{~cm}$ of soil was sampled using a hand shovel. Soil samples were brought to the laboratory and subjected to procedures for determining sinigrin concentrations. Sinigrin was extracted from soil and quantified using high performance liquid chromatography (Agilent 1100, Agilent Technologies) following procedures in Wood et al. (2020). At 14 and 28 DAA, chile pepper plants were evaluated for visual symptoms for MSM-induced injury using the rating scale from the greenhouse study. At 30 to 35 DAA, marketable fruits were harvested by hand from central 4-m sections of plot rows. Criteria for marketable fruits were those that were straight, green, without disease symptoms, and at least $10 \mathrm{~cm}$ in length. The fruits were weighed in the field to determine fresh weights.

MSM effects on Palmer amaranth emergence were determined with artificial seedbanks that were constructed in the field immediately after MSM incorporation but before the irrigation that followed MSM application. Artificial seedbanks were within PVC pipes ( $6 \mathrm{~cm}$ diameter, $7 \mathrm{~cm}$ height) that were incorporated into soil so that the pipe tops formed a lip $2 \mathrm{~cm}$ above the soil surface. Pipes were filled with soil from the surrounding plot, meaning that artificial seedbanks contained MSM-treated or nontreated soil. Fifty Palmer amaranth seeds were then buried $1 \mathrm{~cm}$ deep in each seedbank. Palmer amaranth seedling densities were recorded, and seedlings removed, every $7 \mathrm{~d}$ for $28 \mathrm{~d}$. Cumulative emergence through 28 DAA was used for data analysis.

The effect of MSM mixed in field soil on mycelial growth of Phytophthora capsici was investigated by using a bioassay conducted in the laboratory. For this assay, soil samples from each plot were collected using a hand shovel (sampling depth $7 \mathrm{~cm}$ ). Magenta boxes $(6.35 \mathrm{~cm}$ length, $6.35 \mathrm{~cm}$ width, 9.52 $\mathrm{cm}$ depth) were half-filled with $180 \mathrm{~g}$ soil. Soil was then hydrated until a thin film of water appeared on the surface. The lids of the magenta boxes contained V8 agar medium inoculated centrally with a mycelium plug of $P$. capsici grown for $5 \mathrm{~d}$ on autoclaved V8 agar media in growth chambers set to $25^{\circ} \mathrm{C}$. The lids were inverted over magenta boxes containing field soil following the protocol described by Sanogo (2007). Boxes were then sealed and arranged on the laboratory bench in a paired plot design that matched the spatial arrangement of experimental plots in the field. Magenta boxes were maintained at room temperature of $22 \pm 3{ }^{\circ} \mathrm{C}$. After $4 \mathrm{~d}$, the diameters of $P$. capsici cultures were measured. Mycelial growth was determined as the difference between the $P$. capsici diameter at $4 \mathrm{~d}$ and the $P$. capsici diameter at the start of the bioassay. Bioassays were stopped at $4 \mathrm{~d}$ because at this time, the mycelium reached the rim of the lids in the control treatments. After $4 \mathrm{~d}$, all P. capsici plugs were removed from magenta box lids and transferred to new V8 agar in petri plates. These petri plates were maintained at room temperature for $4 \mathrm{~d}$. Then, diameters of mycelial colonies of $P$. capsici were measured.

Data analysis. All statistical analyses were performed using the open source statistical software program R (v.3.0.1, The R Foundation for Statistical Computing, http:// www.r-project.org). For the greenhouse study, photosynthetic rates were analyzed separately for each time point with analysis of variance followed by mean separation with Tukey's test for post hoc analysis. For greenhouse study response variables including aboveground fresh weight, dry weight, plant height, and leaf area; data were analyzed using linear mixed-effects models using the R library lme4 (Bates et al., 2015). In these models, runs and replicates within runs were random effects, and MSM treatments were the fixed effects. Visual injury rating data were analyzed by Friedman's test for nonparametric data. Preliminary analyses indicated that visual injury ratings for all MSM treatments were consistent between the two experimental runs $(P>0.05)$, and therefore, visual injury rating data from the experimental runs were combined for this analysis.

For the field study, yield data were separately analyzed for each site because this study aimed to assess consistency in yield responses to MSM applied at sites that differed in cultivar, soil type, and row spacing. Within each site, yield differences between MSM-treated plots and nontreated control plots were assessed with paired $t$ tests that were appropriate for the paired sample design used in the field study. For studies confirming weed and pathogen suppression from MSM, data were analyzed with mixed-effect models that treated site and replication within site as random effects, and MSM treatment as the fixed effect. Mixed-effect models were used for data from the weed and pathogen suppression studies because these confirmational studies aimed to make overall treatment comparisons that were not specific to site (Fernandez, 2007). For weed density data, generalized linear mixed models were fit with negative binomial probability distributions using the R library lme4 (Bates et al., 2015). For mycelial growth data, linear mixed models were produced using the $\mathrm{R}$ library lme4.

\section{Results}

Greenhouse study. At 14 DAA, the percentages of plants that survived were $100 \%$ for the control, $95.8 \%$ for the low-incorporated treatment, $95.8 \%$ for the high-incorporated 
Table 1. Aboveground fresh and dry biomass, height, leaf area, and visual injury for chile pepper plants subjected to mustard seed meal (MSM) treatments that differed in MSM rate and application method. Plant measurements were taken $14 \mathrm{~d}$ after MSM application. The experiment was conducted in a greenhouse using a sandy loam soil collected from the field. Data are means $\pm \mathrm{sE}(\mathrm{n}=8)$. Means within a column that share the same letter are not different at $P<0.05$.

\begin{tabular}{|c|c|c|c|c|c|}
\hline Treatment $^{z}$ & Aboveground fresh biomass (g) & Aboveground dry biomass (g) & Leaf area $\left(\mathrm{cm}^{2}\right)$ & $\mathrm{Ht}(\mathrm{cm})$ & Injury rating $^{y}$ \\
\hline Control & $31.4 \pm 4.42 \mathrm{a}$ & $5.8 \pm 0.77 \mathrm{a}$ & $569.9 \pm 83.87 \mathrm{a}$ & $20.9 \pm 1.90 \mathrm{a}$ & $0 \pm 0 \mathrm{a}$ \\
\hline Low incorporated & $25.0 \pm 2.31 \mathrm{ab}$ & $4.6 \pm 0.49 \mathrm{a}$ & $483.3 \pm 50.07 \mathrm{ab}$ & $18.0 \pm 1.61 \mathrm{a}$ & $1.0 \pm 0.35 \mathrm{ab}$ \\
\hline Low surface & $18.0 \pm 3.88 \mathrm{~b}$ & $3.2 \pm 0.76 \mathrm{~b}$ & $362.0 \pm 84.57 \mathrm{~b}$ & $12.7 \pm 2.41 \mathrm{~b}$ & $1.9 \pm 0.69 \mathrm{ab}$ \\
\hline High incorporated & $25.9 \pm 4.21 \mathrm{a}$ & $4.8 \pm 0.79 \mathrm{a}$ & $487.1 \pm 88.71 \mathrm{ab}$ & $19.3 \pm 1.98 \mathrm{a}$ & $1.7 \pm 0.51 b$ \\
\hline High surface & $8.7 \pm 3.77 \mathrm{c}$ & $2.1 \pm 0.75 \mathrm{c}$ & $151.3 \pm 76.98 \mathrm{c}$ & $8.1 \pm 2.98 \mathrm{c}$ & $7.0 \pm 1.23 \mathrm{c}$ \\
\hline
\end{tabular}

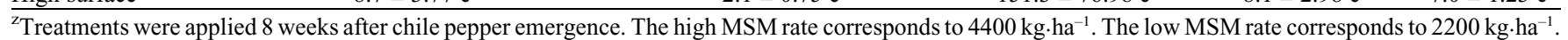

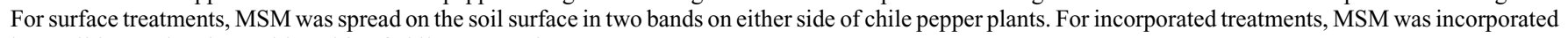
into soil in two bands on either side of chile pepper plants

${ }^{\mathrm{y}}$ Injury rating was done on a 0 to 10 scale, where 0 signifies no damage and 10 signifies plant death.

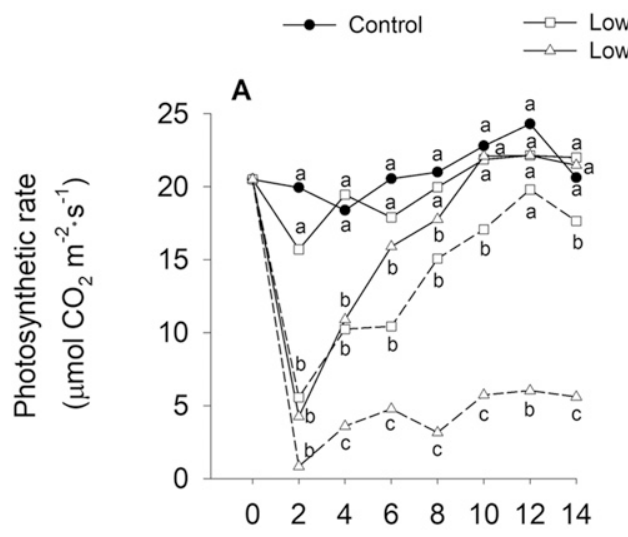

Day after mustard seed meal application

Fig. 1. Chile pepper photosynthetic rates following mustard seed meal (MSM) applications in a greenhouse study during experimental run 1 (A) and experimental run 2 (B). MSM was applied 8 weeks after chile pepper emergence at two rates and using two application methods (spread on the soil surface and incorporated in soil at depth of $5 \mathrm{~cm}$ ). The high-application rate corresponded to $4400 \mathrm{~kg} \cdot \mathrm{ha}^{-1}$ and the low-application rate corresponded to $2200 \mathrm{~kg} \cdot \mathrm{ha}^{-1}$. Data points are means $(\mathrm{n}=4)$. Within a time point, means that share the same letter are not different at $P<0.05$.

treatment, $79.2 \%$ for the low surface treatment, and $37.5 \%$ for the high surface treatment $(n=24$ for each treatment). Surface treatments caused symptoms of injury including plant stunting, drooping and detachment of lower leaves, leaf chlorosis, and plant death (Table 1). Injury symptoms were most severe for the high surface treatment. For incorporated treatments, chile pepper plant heights, aboveground fresh and dry weights, and leaf areas were similar to the control at 14 DAA.

The effects of MSM on chile pepper were evident before 14 DAA. For experimental run 1 , chile pepper photosynthetic rates at $2 \mathrm{DAA}$ were lower than the control for all MSM treatments except the low-incorporated treatment (Fig. 1A). For the high-incorporated treatment, chile pepper photosynthetic rates recovered to levels comparable to those in the control treatment at 12 DAA, although photosynthetic rates in the high-incorporated treatment were less than those in the control at 14 DAA. Throughout the duration of experimental run 1, chile pepper photosynthetic rates for the high surface treatment were less than those in the control treatment. For experimental run 2, MSM initially caused reductions in chile pepper photosynthetic rates; however, by 14 DAA, chile pepper photosynthetic rates were similar between the control and MSM treatments, except for the high surface treatment (Fig. 1B). Similar to experimental run 1 , the high surface treatment caused reductions in chile pepper photosynthetic rates throughout the duration of experimental run 2 .

Field study. From the time of MSM application (0 DAA) to $28 \mathrm{DAA}$, there was a $100 \%$ reduction of sinigrin concentration in soil at Las Cruces and Los Lunas sites, a 99\% reduction in sinigrin concentration in soil at the Las Uvas site, and a 93\% reduction in sinigrin concentration in soil at the Deming site. Although sinigrin was hydrolyzed to produce volatile biocidal compounds at each study site, chile pepper plants did not exhibit visual symptoms of MSM-induced injury (data not shown). Further, at each study site, chile pepper fruit yields for high and low MSM rates were not significantly different from the control $(P>0.05$, Fig. 2$)$.

MSM at $4400 \mathrm{~kg} \cdot \mathrm{ha}^{-1}$ inhibited Palmer amaranth seedling emergence by $89 \%$ compared with control plots (Table 2). MSM at $2200 \mathrm{~kg} \cdot \mathrm{ha}^{-1}$ inhibited Palmer amaranth emergence by $41.5 \%$ compared with control plots. Soil collected from field plots treated with MSM at $4400 \mathrm{~kg} \cdot \mathrm{ha}^{-1}$ reduced $P$. capcisi mycelial growth by $96 \%$ compared with soil collected from control plots (Table 2). For soil collected from plots treated with MSM at $2200 \mathrm{~kg} \cdot \mathrm{ha}^{-1}, P$. capsici mycelial growth was reduced by $70 \%$ compared with $P$. capsici mycelial growth above soil from control plots. When the $P$. capsici plugs were removed from the magenta box lids and transferred to new V8 agar medium in petri plates, the plugs that were previously suspended over MSM-treated soil did not grow, whereas the plugs that were previously suspended over soil from control plots grew, on average, $3.5 \mathrm{~cm}$ in $4 \mathrm{~d}$.

\section{Discussion}

Previous studies determined that preplant, soil-incorporated applications of MSM suppressed emergence of crops including lettuce (Wang et al., 2015), strawberry, sweet corn, potato ( $\mathrm{Yu}$ et al., 2007) and cucumber (Webber et al., 2017). Considering the risks of crop injury from preplant applications of MSM, Webber et al. (2017) implied that MSM applications should be studied in transplanted or emerged crops. Building on the suggestions for further research from Webber et al. (2017) and based on the fact that plant tolerance to a pesticide is related to the size of the plant at the time of application (e.g., Crose et al., 2019), this study evaluated postemergence applications of MSM. The results of this study indicated that MSM applications that are incorporated into soil are safe for established chile pepper plants.

Leaf photosynthetic rates were used to assess recovery from MSM-induced injury in chile pepper plants. This is because glucosinolate degradation products are associated with stomatal closure (Hossain et al., 2013), and leaf gas exchange variables often reflect plant tolerance or intolernace to herbicidal compounds (Kempenaar et al., 2011). Photosynthesis data indicated that MSM spread on the soil surface caused irrecoverable injury to chile pepper plants in the greenhouse. These results were similar to results from previous studies that determined preplant, surface applications of MSM injured crops (Boydston et al., 2011, 2018). Surface applications of MSM may be harmful to crops because the MSM on the soil surface releases isothiocyantes at relatively high concentrations that directly contact the aboveground parts of the crop. Burial of MSM might reduce the 
amount of isothiocyanate that contacts the crop because burial inhibits upward movement of pesticidal volatiles (Vander Wall, 2003). Although this study did not determine concentrations of isothiocyantes in air near chile pepper plants, the results of this study suggest that burial inhibited losses of isothiocyanates from soil, thereby protecting chile pepper plants from irrecoverable MSM-induced injury.

Degradation products from sinigrin in soil, which include isothiocyanates, reach maximum concentrations within 24 to $48 \mathrm{~h}$ of initial hydration (Borek et al., 1994) and dissipate to concentrations half of maximum within days of wetting (Borek et al., 1995). Although it is likely that the pesticidal compounds derived from MSM did not persist in soil for extended periods, MSM amendments to soil reduced emergence of Palmer amaranth in the field. Palmer amaranth is a difficult to control, summer annual weed in New Mexico chile pepper fields (Skaggs et al., 2000). Although Palmer amaranth is capable of rapid growth and high levels of seed production (Ward et al., 2013), Palmer amaranth emergence is suppressed by products of glucosinolate hydrolysis (Norsworthy and Meehan, 2005; Wang et al., 2015). In this study, reduced levels of Palmer amaranth emergence in MSM-treated plots confirmed that the MSM rates $\left(2200 \mathrm{~kg} \cdot \mathrm{ha}^{-1} \mathrm{MSM}\right.$ and $4400 \mathrm{~kg} \cdot \mathrm{ha}^{-1} \mathrm{MSM}$ ) are sufficient for controlling weeds in chile pepper.

MSM mixed with field soil at 2200 $\mathrm{kg} \cdot \mathrm{ha}^{-1}$ MSM and $4400 \mathrm{~kg} \cdot \mathrm{ha}^{-1}$ MSM suppressed $P$. capsici growth under laboratory conditions. This study showed that MSMtreated soils did not just suppress mycelial growth of $P$. capsici, but also killed the pathogen because the mycelia did not grow after mycelia were removed from the MSM treatment. In a previous laboratory study, MSM at $2200 \mathrm{~kg} \cdot \mathrm{ha}^{-1}$ and $4400 \mathrm{~kg} \cdot \mathrm{ha}^{-1}$ inhibited mycelial growth of Verticillium dahliae (Wood et al., 2020), which is another soilborne pathogen that can substantially reduce chile pepper yield. The results from this study, combined with the results of the previous study on $V$. dahliae (Wood et al., 2020), suggest that MSM application rates of 2200 $\mathrm{kg} \cdot \mathrm{ha}^{-1}$ and $4400 \mathrm{~kg} \cdot \mathrm{ha}^{-1}$ are sufficient for suppression of soilborne pathogens in chile pepper; however, these results need to be validated in the field before recommendations can be made. Any recommendations for

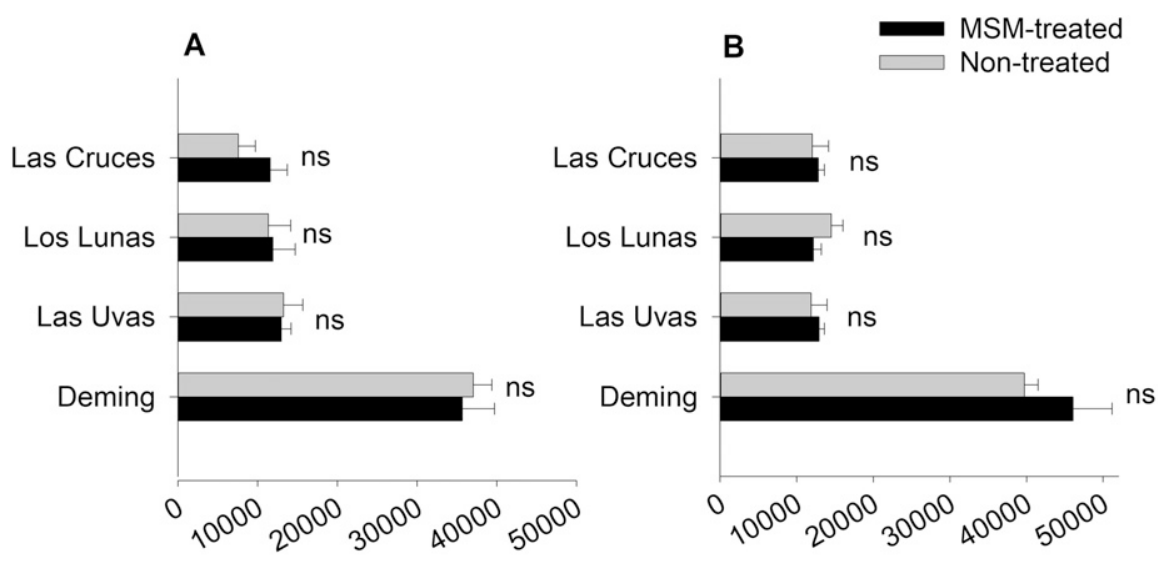

\section{Chile pepper yield $\left(\mathrm{kg} \cdot \mathrm{ha}^{-1}\right)$}

Fig. 2. Chile pepper fruit yield responses to mustard seed meal (MSM) applied at $4400 \mathrm{~kg} \cdot \mathrm{ha}^{-1}$ (A) and $2200 \mathrm{~kg} \cdot \mathrm{ha}^{-1}(\mathbf{B})$ at four sites in New Mexico. MSM was amended to soil between crop rows at 10 to 11 weeks after the chile plant emergence. Each MSM rate was separately tested with paired, nontreated control plots. Data are means $\pm \mathrm{SE}(\mathrm{N}=4)$. NS indicates nonsignificant effect of MSM treatment within a site $(P>0.05)$.

MSM application rates are likely to be influenced by the Brassicaceae species that was used to form the meal. This is because Brassicaceae species differ in the types and concentrations of glucosinolates found in seeds (Chung et al., 2002). MSM in this study was derived from brown mustard, a species that was previously determined to produce seed meals with relatively high glucosinolate concentrations (Chung et al., 2002).

The material and shipping costs for MSM in this study was $\$ 2296 /$ acre $(\$ 5674 /$ ha) for the $2200 \mathrm{~kg} \cdot \mathrm{ha}^{-1}$ treatment, \$4492/acre $(\$ 11,349 / \mathrm{ha})$ for the $4400 \mathrm{~kg} \cdot \mathrm{ha}^{-1}$ treatment. These costs are less than those for soil disinfestation by steaming (Fennimore and Goodhue, 2016; Samtani et al., 2012), but greater than costs for custom applications of synthetic fumigants (Walters et al., 2011). An economic analysis in 2018 determined that the total costs for installing and removing plastic mulch was \$2761/acre (Fonsah and Shealey, 2019), which is similar to the costs for MSM at $2200 \mathrm{~kg} \cdot \mathrm{ha}^{-1}$. If MSM at 2200 $\mathrm{kg} \cdot \mathrm{ha}^{-1}$ improves crop production to degrees equivalent to benefits derived from plastic mulch (Kasirajan and Ngouajio 2012), MSM might be a justifiable expense for growers who either lack the specialized equipment for installing plastic mulch or have concerns for plastic mulch disposal. However, it should be noted that MSM material costs do not include costs for operating application equipment, which will likely include tractor-pulled fertilizer spreaders and implements for shallow cultivation.

Application procedures for fumigants often involve plastic mulches to trap volatile biocidal compounds (Guo et al., 2005). In New Mexico chile pepper production, plastic mulch is not often used. Accordingly, NM chile pepper producers need pest management tools that can be effective without plastic mulch. For MSM without plastic mulch, soil incorporation could reduce loss of volatile biocidal compounds. This assumption is supported by Handiseni and Brown (2009), who reported that MSM incorporated in soil had more herbicidal activity than MSM not incorporated in soil. The combined results of Handiseni and Brown (2009) and this study indicate that soil incorporation is a

Table 2. Parameter estimates, with 97.5\% confidence limits, from generalized linear mixed models for mustard seed meal (MSM) effects on Palmer amaranth (Amaranthus palmeri) seedling emergence in artificial seedbanks and Phytophthora capsici mycelial growth in laboratory assays. MSM was applied at a high rate equivalent to $4400 \mathrm{~kg} \cdot \mathrm{ha}^{-1}$ and low rate equivalent to $2200 \mathrm{~kg} \cdot \mathrm{ha}^{-1}$ and compared against nontreated control plots.

\begin{tabular}{|c|c|c|c|c|c|}
\hline \multirow[b]{2}{*}{ MSM rate } & \multirow[b]{2}{*}{ Parameter $^{z}$} & \multicolumn{2}{|c|}{ Palmer emergence $^{\mathrm{y}}$} & \multicolumn{2}{|c|}{ Phytophthora mycelium growth ${ }^{\mathrm{x}}$} \\
\hline & & Estimate & Seedlings/seedbank & Estimate & Radial growth $(\mathrm{cm})$ \\
\hline \multirow[t]{2}{*}{ High $\left(4400 \mathrm{~kg} \cdot \mathrm{ha}^{-1}\right)$} & Intercept (nontreated) & $2.21(1.467 ; 2.909)$ & 9.1 & $3.45(3.216 ; 3.681)$ & 3.45 \\
\hline & MSM treated & $-2.29(-2.830 ;-1.816)$ & 1.0 & $-3.31(-3.639 ;-2.986)$ & 0.14 \\
\hline \multirow[t]{2}{*}{ Low $\left(2200 \mathrm{~kg} \cdot \mathrm{ha}^{-1}\right)$} & Intercept (nontreated) & $2.04(1.171 ; 2.881)$ & 7.7 & $3.40(3.050 ; 3.755)$ & 3.40 \\
\hline & MSM treated & $-0.54(-1.964 ;-0.031)$ & 4.5 & $-2.39(-2.895 ;-1.898)$ & 1.01 \\
\hline
\end{tabular}

${ }^{\mathrm{z}}$ Nontreated control plots were coded as the reference category in the generalized linear mixed models. Parameter estimate are presented in the linked scale, followed by back-transformed means predicted by the model. Parameter estimates for the intercept correspond to the means for nontreated control plots. Estimates for the parameter "MSM treated" represent the differences between nontreated and treated plots. MSM-treated parameter estimates with confidence intervals not overlapping zero are statistically significant.

${ }^{\mathrm{y}}$ Palmer emergence in a polyvinyl chloride pipe $(6 \mathrm{~cm}$ diameter $\times 7 \mathrm{~cm}$ height $)$ that was seeded with 50 Palmer amaranth seeds and incorporated into soil.

${ }^{\mathrm{x}}$ Mycelium plugs ( $5 \mathrm{~mm}$ in diameter) of Phytophthora capsici were placed on a V8 agar medium that was suspended over MSM-treated and nontreated field soils in magenta boxes. Radial growth from mycelium plugs was measured after $96 \mathrm{~h}$ of incubation at room temperature of $22 \pm 3{ }^{\circ} \mathrm{C}$. 
promising way to prevent crop phytotoxicity of MSM and enhance its pesticidal activity.

In addition to a biopesticide, MSM potentially serves as a fertilizer because MSM contains $5 \%$ to $6 \%$ nitrogen by weight (Gale et al., 2006). However, in this study, MSM did not enhance chile pepper yield, suggesting that our postemergence applications of MSM did not fertilize chile pepper plants. Similarities in crop yield between MSM-treated plots and nontreated control plots might also have been caused by the low abundance of weeds and soilborne pathogens in control plots at each study site. Further research that attempts to develop procedures for using MSM as both a fertilizer and biopesticide should be conducted in fields with high levels of weeds and soilborne diseases. Such study sites would clarify the fertilizer and pesticidal benefits of postemergence applications of MSM.

\section{Conclusion}

MSM can be applied after crop emergence to target late-season weeds and soilborne pathogens in chile pepper. For these postemergence applications of MSM, we recommend incorporating MSM into soil that occurs between crop rows, thereby minimizing opportunity for MSM to injure chile pepper plants. Although this study determined that postemergence, incorporated applications of MSM do not cause irrecoverable injury and yield loss in chile pepper, further research is needed to determine the safety of postemergence applications of MSM in other crops. Improved knowledge of crop tolerance to postemergence applications of MSM may increase the use of this biopesticide for simultaneously targeting weeds and soilborne diseases in conventional and organic cropping systems.

\section{Literature Cited}

Bangarwa, S.K., J.K. Norsworthy, J.D. Mattice, and E.E. Gbur. 2011. Glucosinolate and isothiocyanate production from Brassicaceae cover crops in a plasticulture production system. Weed Sci. 59:247-254, doi: 10.1614/WSD-10-00137.1.

Bañuelos, G.S. and B.D. Hanson. 2010. Use of selenium-enriched mustard and canola seed meals as potential bioherbicides and green fertilizer in strawberry production. HortScience 45:1567-1572, doi: 10.21273/HORTSCI.45.10.1567.

Bates, D., M. Maechler, B. Bolker, and S. Walker. 2015. Fitting linear mixed-effects models using lme4. J. Stat. Softw. 67:1-48. <https://www.jstatsoft.org/v067/i01>.

Borek, V., M.J. Morra, P.D. Brown, and J.P. McCaffrey. 1994. Allelochemicals produced during sinigrin decomposition in soil. J. Agr. Food Chem. 42:1030-1034, doi: 10.1021/ jf00040a037.

Borek, V., M.J. Morra, P.D. Brown, and J.P. McCaffrey. 1995. Transformation of the glucosinolatederived allelochemicals allyl isothiocyanate and allylnitrile in soil. J. Agr. Food Chem. 43:19351940, doi: 10.1021/jf00055a033.

Bosland, P.W. 2015. The history, development, and importance of the New Mexican pod-type chile pepper to the United States and world food industry. Plant Breed. Rev. 39:283-324.

Boydston, R.A., S.F. Vaughn, C.L. Webber, III, and B. Chaves-Cordoba. 2018. Evaluating mustard seed meal for weed suppression in potato (Solanum tuberosum). J. Agr. Sci. 10:48-57, doi: 10.5539/jas.v10n2p48.

Boydston, R.A., M. Morra, V. Borek, L. Clayton, and S. Vaughn. 2011. Onion and weed response to mustard (Sinapis alba) seed meal. Weed Sci. 59:546-552, doi: 10.1614/WS-D-10-00185.1.

Bhandari, S.R., J.S. Jo, and J.G. Lee. 2015. Comparison of glucosinolate profiles in different tissues of nine brassica crops. Molecules 20:15827-15841, doi: 10.3390/molecules200915827.

Breier, A., L. Turi-Nagy, A. Ziegelhöffer, R. Monosíková, and A. Dzurba. 1989. Hypothetical structure of the ATP-binding site of $\left(\mathrm{Na}^{+}+\right.$ $\mathrm{K}^{+}$)-ATPase. Gen. Physiol. Biophys. 8:283286.

Charron, C.S. and C.E. Sams. 2017. Inhibition of Pythium ultimum and Rhizoctonia solani by shredded leaves of brassica species. J. Amer. Soc. Hort. Sci. 124:462-467, doi: 10.21273/ JASHS.124.5.462.

Chung, W.C., J.W. Huang, H.C. Huang, and J.F. Jen. 2002. Effect of ground Brassica seed meal on control of Rhizoctonia damping-off of cabbage. Can. J. Plant Pathol. 24:211-218, doi: $10.1080 / 07060660309506998$.

Crose, J., M. Manuchehri, and T. Baughman. 2019. Horseweed (Conyza canadensis) management in Oklahoma winter wheat. Weed Technol. 34:1-23, doi: 10.1017/wet.2019.99.

Doheny-Adams, T., K. Redeker, V. Kittipol, I. Bancroft, and S.E. Hartley. 2017. Development of an efficient glucosinolate extraction method. Plant Methods 13:17, doi: 10.1186/s13007017-0164-8.

Earlywine, D.T., R.J. Smeda, T.C. Teuton, C.E. Sams, and X. Xiong. 2010. Evaluation of oriental mustard (Brassica juncea) seed meal for weed suppression in turf. Weed Technol. 24:440-445, doi: 10.1614/wt-d-09-00058.1.

Fayzalla, E.A., E. El-Barougy, and M.M. El-Rayes. 2009. Control of soil-borne pathogenic fungi of soybean by biofumigation with mustard seed meal. J. Appl. Sci. 9:2272-2279, doi: 10.3923/ jas.2009.2272.2279.

Fennimore, S.A. and R.E. Goodhue. 2016. Soil disinfestation with steam: A review of economics, engineering, and soil pest control in California strawberry. Intl. J. Fruit Sci. 16:7183, doi: 10.1080/15538362.2016.1195312.

Fernandez, G.C.J. 2007. Design and analysis of commonly used comparative horticultural experiments. HortScience 42:1052-1069, doi: 10.21273/hortsci.42.5.1052

Fonsah, E.G. and J. Shealey. 2019. Estimated cost per acre of removing and replacing plastic mulch damaged by Hurricane Michael in Georgia. Univ. Georgia Ext. 1 Dec. 2020. $<$ https://site.extension.uga.edu/aaecext/2019/ 09/estimated-cost-per-acre-of-removing-andreplacing-plastic-mulch-damaged-by-hurricanemichael-in-georgia/>.

Gale, E.S., D.M. Sullivan, C.G. Cogger, A.I. Bary, D.D. Hemphill, and E.A. Myhre. 2006. Estimating plant-available nitrogen release from manures, composts, and specialty products. J. Environ. Qual. 35:2321-2332, doi: 10.2134/ jeq2006.0062.

Gigot, J.A., I.A. Zasada, and T.W. Walters. 2013. Integration of brassicaceous seed meals into red raspberry production systems. Appl. Soil Ecol. 64:23-31, doi: 10.1016/j.apsoil.2012.10.013.

Guo, M., S.R. Yates, S.K. Papiernik, and W. Zheng. 2005. Incompatibility of metam sodium with halogenated fumigants. Pest Manag. Sci. 61:467-476, doi: 10.1002/ps.960.

Handiseni, M. and J. Brown. 2009. Fungicidal and herbicidal properties of Brassica napus, Brassica juncea and Sinapis alba seed meal amended soils and phytotoxicity on tomato and pepper. Univ. Idaho, Moscow, ID, MS Thesis.

Hawkes, B.J., J.D. Libbin, and B.A. Jones. 2008. Chile production in New Mexico and northern Mexico. J. Amer. Soc. Farm Manag. Rural Appraisers 71:83-92.

Hoagland, L., L. Carpenter-Boggs, J.P. Reganold, and M. Mazzola. 2008. Role of native soil biology in brassicaceous seed meal-induced weed suppression. Soil Biol. Biochem. 40:1689-1697, doi: 10.1016/ j.soilbio.2008.02.003.

Hossain, M.S., W. Ye, M.A. Hossain, E. Okuma, M. Uraji, Y. Nakamura, I.C. Mori, and Y. Murata. 2013. Glucosinolate degradation products, isothiocyanates, nitriles, and thiocyanates, induce stomatal closure accompanied by peroxidase-mediated reactive oxygen species production in Arabidopsis thaliana. Biosci. Biotechnol. Biochem. 77:977-983, doi: 10.1271/bbb.120928.

Jiang, L., S. Sanogo, and P.W. Bosland. 2015. Using recombinant inbred lines to monitor changes in the race structure of Phytophthora capsici in chile pepper in New Mexico. Plant Health Prog. 16:235-240, doi: 10.1094/php-rs15-0034.

Kasirajan, S. and M. Ngouajio. 2012. Polyethylene and biodegradable mulches for agricultural applications: A review. Agron. Sustain. Dev. 32:501-529, doi: 10.1007/s13593-011-0068-3.

Kempenaar, C., L.A.P. Lotz, J.F.H. Snel, V. Smutny, and H.J. Zhang. 2011. Predicting herbicidal plant mortality with mobile photosynthesis meters. Weed Res. 51:12-22, doi: 10.1111/j.1365-3180.2010.00823.x.

Kirkegaard, J.A. and M. Sarwar. 1998. Biofumigation potential of brassicas: I. Variation in glucosinolate profiles of diverse field-grown brassicas. Plant Soil 201:71-89, doi: 10.1023/ A:1004381129991.

Leblová-Svobodová, S. and J. Koštî́. 1962. Action of isothiocyanates on germinating plants. Experientia 18:554-555, doi: 10.1007/BF02172173.

Matheron, M.E. and M. Porchas. 2015. Effectiveness of nine different fungicides for management of crown and root rot of chile pepper plants caused by Phytophthora capsici. Plant Health Prog. 16:218-222, doi: 10.1094/php-rs15-0028.

Mayton, H.S., C. Olivier, S.F. Vaughn, and R. Loria. 1996. Correlation of fungicidal activity of brassica species with allyl isothiocyanate production in macerated leaf tissue. Phytopathology 86:267-271, doi: 10.1094/Phyto-86267.

Meyer, S.L.F., I.A. Zasada, S.B. Orisajo, and M.J. Morra. 2011. Mustard seed meal mixtures: management of Meloidogyne incognita on pepper and potential phytotoxicity. J. Nematol. 43:7-15.

Meyer, S.F., I.A. Zasada, S.M. Rupprecht, M.J. VanGessel, C.R. Hooks, M.J. Morra, and K.L. Everts. 2015. Mustard seed meal for management of root-knot nematode and weeds in tomato production. HortTechnology 25(2):192-202, doi: 10.21273/HORTTECH.25.2.192.

Norsworthy, J.K. and J.T. Meehan. 2005. Use of isothiocyanates for suppression of Palmer amaranth (Amaranthus palmeri), pitted morningglory (Ipomoea lacunosa), and yellow nutsedge (Cyperus esculentus). Weed Sci. 53:884-890, doi: 10.1614/WS-05-056R.1. 
Øverby, A., M.S. Bævre, O.P. Thangstadf, and A.M. Bones. 2015. Disintegration of microtubules in Arabidopsis thaliana and bladder cancer cells by isothiocyanates. Front. Plant Sci. 6:1-10, doi: 10.3389/fpls.2015.00006.

Perecin, D., G. Ferraudo, C. Azania, and A. Schiavetto. 2015. Statistical analysis for correlated paired-plot designs. Amer. J. Exp. Agr. 9:1-7, doi: 10.9734/AJEA/2015/20722.

Rothlisberger, K.L., F.M. Hons, T.J. Gentry, and S.A. Senseman. 2012. Oilseed meal effects on the emergence and survival of crop and weed species. Appl. Environ. Soil Sci. 2012:1-10, doi: 10.1155/2012/769357.

Samtani, J.B., C. Gilbert, J.B. Weber, K.V. Subbarao, R.E. Goodhue, and S.A. Fennimore. 2012. Effect of steam and solarization treatments on pest control, strawberry yield, and economic returns relative to methyl bromide fumigation. HortScience 47:64-70, doi: 10.21273/ HORTSCI.47.1.64

Sanogo, S. and J. Carpenter. 2006. Incidence of Phytophthora blight and Verticillium wilt within chile pepper fields in New Mexico. Plant Dis. 90:291-296, doi: 10.1094/PD-90-0291.

Sanogo, S. 2007. Interactive effects of two soilborne pathogens, Phytophthora capsici and Verticillium dahliae, on chile pepper. Phytopathology 97:37-43, doi: 10.1094/PHYTO-970037.

Sanogo, S. and P. Ji. 2013. Water management in relation to control of Phytophthora capsici in vegetable crops. Agr. Water Mgt. 129:113119, doi: 10.1016/j.agwat.2013.07.018.

Schroeder, J. 1993. Late-season interference of spurred anoda in chile peppers. Weed Sci. 41:172-179.
Shrestha, A., A. Rodriguez, S. Pasakdee, and G. Bañuelos. 2015. Comparative efficacy of white mustard (Sinapis alba) and soybean (Glycine max) seed meals as bioherbicides in organic broccoli (Brassica oleracea) and spinach (Spinacea oleracea) production. Commun. Soil Sci. Plant Anal. 46:33-46, doi: 10.1155/2012/ 769357.

Skaggs, R., M. Decker, and D. VanLeeuwen. 2000. A survey of southern New Mexico chile producers: Production, practices and problems. New Mex. State Univ., Agr. Exp. Sta. Bul. 782. $<$ https://aces.nmsu.edu/pubs/research/ agronomy/BL782/welcome.html>.

Snyder, A., M.J. Morra, J. Johnson-Maynard, and D.C. Thill. 2009. Seed meals from brassicaceae oilseed crops as soil amendments: Influence on carrot growth, microbial biomass nitrogen, and nitrogen mineralization. HortScience 44:354 361, doi: 10.21273/HORTSCI.44.2.354.

Urbancsok, J., A.M. Bones, and R. Kissen. 2017. Glucosinolate-derived isothiocyanates inhibit arabidopsis growth and the potency depends on their side chain structure. Intl. J. Mol. Sci. 18:1-18, doi: 10.3390/ijms18112372.

U.S. Dept. Agr., National Agricultural Statistics Service (NASS). 2019. 2018 New Mexico chile production. 5 Jan. 2021. <https://www.nass.usda. gov/Statistics_by_State/New_Mexico/Publications/ News_Releases/2019/NM-2018-Chile-Production. pdf $>$.

Vander Wall, S.B. 2003. How rodents smell buried seeds: A model based on the behavior of pesticides in soil. J. Mammal. 84:1089-1099, doi: 10.1644/BPR-003.

Walters, T., J. Gigot, and I. Zasada. 2011. Preplant soil fumigation and alternatives for berry pro- duction. Washington State Univ. Extension Fact Sheet FS064E. 1 Dec. 2020. <http://whatcom. wsu.edu/ag/documents/smallfruit/FS064E.pdf>.

Ward, S.M., T.M. Webster, and L.E. Steckel. 2013. Palmer amaranth (Amaranthus palmeri): A review. Weed Technol. 27:12-27. <https:// www.jstor.org/stable/23358302>.

Wang, X., M. Gu, G. Niu, and P.A. Baumann. 2015. Herbicidal activity of mustard seed meal (Sinapis alba "IdaGold" and Brassica juncea 'Pacific Gold') on weed emergence. Ind. Crops Prod. 77:1004 1013, doi: 10.1016/j.indcrop.2015.09.070.

Webber, C.L., III, P.M. White, Jr., R.A. Boydston, and J.W. Shrefler. 2017. Impact of mustard seed meal applications on direct-seeded cucurbits and weed control. J. Agr. Sci. 9:81-90, doi: 10.5539/jas.v9n8p81.

Wood, J.B. 2019. Mustard seed meal suppression of Palmer amaranth (Amaranthus palmeri) and Verticillium dahliae in chile pepper. New Mexico State Univ., Las Cruces, NM, MS Thesis.

Wood, J.B., B.J. Schutte, I. Guzman, and S. Sanogo. 2020. Water availability influences the inhibitory effects of mustard seed meal on Palmer amaranth (Amaranthus palmeri) and Verticillium dahliae. Weed Technol. 34:756763, doi: 10.1017/wet.2020.52.

Yu, Q., R. Tsao, M. Chiba, and J. Potter. 2007. Elucidation of the nematicidal activity of bran and seed meal of oriental mustard (Brassica juncea) under controlled conditions. J. Food Agr. Environ. 5:374-379.

Yu, Q., R. Tsao, M. Chiba, and J. Potter. 2005. Selective nematicidal activity of allyl isothiocyanate. J. Food Agr. Environ. 3:218-221. 